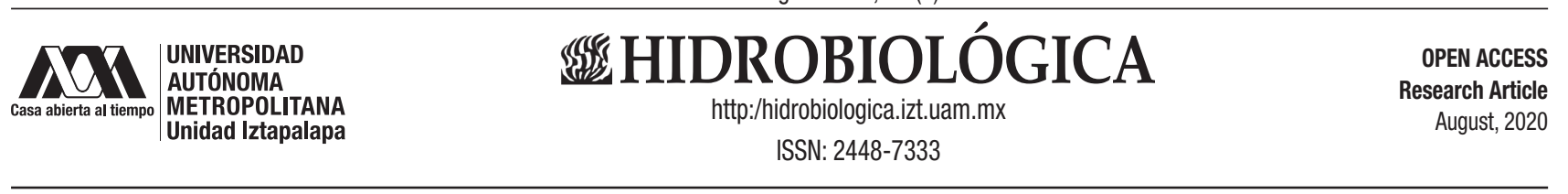

\title{
Horizontal transmission of ice-ice disease in seaweed Kappaphycus alvarezii (Doty) L. M. Liao (Gigartinales, Rhodophyta)
}

Transmisión horizontal de la enfermedad del hielo en Kappaphycus alvarezii (Doty) L. M. Liao (Gigartinales, Rhodophyta)

\author{
${\text { Muhammad } \text { Aris }^{* \odot} \text { and Rusmawati Labenua }}^{2}$
}

${ }^{1}$ Department of Aquaculture, Fisheries and Marine of Faculty, Khairun of University. Ternate, 97719. Indonesia

2 Departement of Aquatic Resource Management, Fisheries and Marine of Faculty, Khairun of University. Ternate, 97719. Indonesia

*Corresponding author:

Muhammad Aris: e-mail:

amboasse100676@gmail.com

To quote as:

Aris, M. \& R. Labenua. 2020. Horizonta transmission of ice-ice disease in seaweed Kappaphycus alvarezii (Doty) L. M. Liao (Gigartinales, Rhodophyta). Hidrobiológica 30 (2): 155-161.

\section{DOl:10.24275/uam/izt/dcbs/hidro/2020v30n2/} Muhammad

\section{ABSTRACT}

Background: Kappaphycus alvarezii seaweed is a major commodity of important economic value fishery cultivation that has been developed in many countries. The demand for $K$. alvarezii seaweed continues to increase because it produces carrageenan which is commonly used as the main raw material in many industrial activities. However, K. alvarezii seaweed farming is inseparable from several obstacles. In the seaweed culture system, ice-ice disease is a major obstacle because it can harm the cultivation business. Ice-ice disease causes a decrease in seaweed production. Bacteria play a role in the development of ice-ice disease in seaweed cultivation. Aquatic organisms infected with bacteria indirectly cause damage to tissue. The spread of bacterial diseases in aquatic organisms can occur vertically or horizontally. Goals: This research aims to study the horizontal transmission of ice-ice disease on growth, carrageenan content, and changes in the structure of the $K$. alvarezii seaweed tissue which were tested in-vivo. Methods: This study uses healthy seaweed thalus weighing $35 \mathrm{~g}$ and seaweed thallus affected by ice-ice weighing $30 \mathrm{~g}(\mathrm{~A}), 35 \mathrm{~g}(\mathrm{~B}), 40 \mathrm{~g}(\mathrm{C})$ and $45 \mathrm{~g}$ (D). The parameters observed were morphological changes, carrageenan content and tissue changes with histological analysis. Result: The results of this research indicate that the transmission of ice-ice disease can occur horizontally from thallus affected by ice-ice to healthy thallus. This transmission causes discoloration that shows symptoms of ice-ice attack on healthy seaweed $K$. alvarezii. This discoloration is accompanied by a decrease in thallus weight. Transmission also causes changes in the structure of the tissue in the form of lysis in the tissue and reduce the content of carrageenan in K. alvarezii seaweed. Conclusions: Based on this research, it can be concluded that the spread of ice-ice disease in seaweed causes color change, weight loss, changes in tissue structure, and reduce the quality of carrageenan.

Keywords: Kappaphycus alvarezii, ice-ice disease, horizontal transmission, histology, carrageenan content.

\section{RESUMEN}

Antecedentes: Kappaphycus alvarezii es un importante producto en la acuicultura de valor económico en muchos países. La demanda de algas $K$. alvarezii continúa aumentando porque produce carragenina, que se usa comúnmente como la principal materia prima en muchas actividades industriales. Sin embargo, el cultivo de algas marinas de K. alvarezii es inseparable de varios obstáculos. En el sistema de cultivo de algas marinas, la enfermedad de hielo-hielo una problemática importante porque puede dañar el negocio del cultivo. La enfermedad de hielo-hielo causa una disminución en la producción de algas. Las bacterias juegan un papel en el desarrollo de la enfermedad de hielo-hielo en el cultivo de algas. Los organismos acuáticos infectados con bacterias causan daños indirectos en los tejidos. La propagación de enfermedades bacterianas en organismos acuáticos puede ocurrir vertical u horizontalmente. Objetivos: Esta investigación tiene como objetivo estudiar la transmisión horizontal de la enfermedad de hielo-hielo en el crecimiento, el contenido de carragenina y los cambios en la estructura de la red de algas marinas $K$. alvarezii que se probaron in vivo. Métodos: Este estudio utilizó talos de algas sanas que pesaron $35 \mathrm{~g}$ y talos de algas marinas afectadas por la enfermedad del hielo-hielo que pesaron $30 \mathrm{~g}(\mathrm{~A}), 35 \mathrm{~g}$ (B), $40 \mathrm{~g}$ (C) y $45 \mathrm{~g}$ (D). Los parámetros observados fueron cambios morfológicos, contenido de carragenano y cambios tisulares con análisis histológico. Resultados: Los resultados de esta investigación indican que la transmisión de la enfermedad de hielo-hielo puede ocurrir horizontalmente desde el talo afectado por el hielo hasta el talo sano. Esta transmisión provoca decoIoración y una disminución en el peso del talo. La transmisión también provoca cambios en la estructura del tejido en forma de lisis en la red y reduce el contenido de carragenina en las algas $K$. alvarezii. Conclusiones: Con base en esta investigación, se puede concluir que la propagación de la enfermedad del hielo-hielo en 
las algas marinas causa cambios de color, pérdida de peso, cambios en la estructura de los tejidos y reducción de la calidad de la carragenina.

Palabras clave: Algas rojas, acuicultura, bacterias, carragenina, histología, morfología.

\section{INTRODUCTION}

Kappaphycus alvarezii (Doty) L. M. Liao seaweed is a major economically important fishery commodity (Ask \& Azanza, 2002; Bixler \& Porse, 2010; Bindu \& Levine, 2011; Zuniga-Jara \& Marin-Riffo, 2015).The development of the $K$. alvarezii culture is very fast due to the demand for carrageenan, which is commonly used as the main raw material in many industrial activities (Munoz et al., 2004; Yunque et al., 2011; Barbosa et al., 2013; Hurtado et al., 2015; Porse \& Rudolph, 2017).

Kappaphycus alvarezii is a seaweed commodity that has been developed in many countries, such as Indonesia, Malaysia, the Philippines, Vietnam and several other countries (Hung et al., 2009; Nadirah et al., 2012; Hurtado et al., 2015; Kasim \& Mustafa, 2017). In the seaweed culture system, ice-ice disease is a major obstacle because it can harm cultivation efforts (Vairappan, 2006; Solis et al., 2010; Luhan et al., 2015). Ice-ice disease causes a decrease in seaweed farming production ranging from 70\%-100\% (Loureiro et al., 2010).

Outbreaks of ice-ice diseases attacking $K$. alvarezii cultivation development activities have been reported in various regions of Indonesia, including Karimunjawa Islands, East Java; Bungin Island and Muna Island, Southeast Sulawesi; and Seribu Islands, DKI Jakarta (Porse \& Rudolph, 2017; Syafitri et al., 2017; Aeni et al., 2019).

Bacteria play a role in the development of ice-ice disease in seaweed cultivation. The bacteria that cause ice-ice disease in $K$. alvarezii are Vibrio, Aeromonas, Cytophaga, Flavobacterium, Pseudomonas and Bacillus (Largo et al., 1995; Riyaz et al., 2019). Aquatic organisms infected with bacteria indirectly cause damage to tissue. Changes in tissue structure make aquatic organisms sick and even cause death (Korun \& Timur, 2008; Oh et al., 2019).

Disease transmission in aquatic organisms can occur vertically or horizontally. Horizontal spread is the process of transferring pathogens from disease-infected organisms to healthy organisms (Manin \& Ransangan, 2011; Karthikeyan \& Sudhakaran, 2018; Ben-Asher et al., 2019). This study aims to determine the horizontal transmission of ice disease on growth, carrageenan content and changes in the tissue structure of $K$. alvarezii seaweed.

\section{MATERIALS AND METHODS}

\section{Sample Collection}

Kappaphycus alvarezii seaweed samples used were healthy seaweed with a wet weight of $35 \mathrm{~g}$ obtained from the $K$. alvarezii seaweed aquaculture in Kupang, East Nusa Tenggara, Indonesia, whereas the wet weight of seaweed that was attacked by ice-ice was $30 \mathrm{~g}$ (treatment $\mathrm{A}$ ), $35 \mathrm{~g}$ (treatment B), $40 \mathrm{~g}$ (treatment C) and $45 \mathrm{~g}$ (treatment D) obtained from the waters of Panggang Island, DKI Jakarta, Indonesia (S 05\%44' $30,7^{\prime \prime}$ dan E $\left.106^{\circ} 36^{\prime} 04^{\prime \prime}\right)$. In addition, there was also a negative control treatment as a comparison to treatment $A, B, C$ and D. Negative control, was a treatment with thallus free of ice-ice disease.

\section{Container Preparation}

This test was carried out in vivo with an aquarium container of $45 \mathrm{~cm} \mathrm{x}$ $30 \mathrm{~cm} \times 30 \mathrm{~cm}$, the volume of seawater media used was 80 liters. The values of each water quality parameter especially temperature, salinity, and dissolved oxygen are maintained in an ideal range. Temperature $27-29^{\circ} \mathrm{C}$, salinity 30-35 ppt, and dissolved oxygen 4.8-6.2 mg / L.

\section{Seaweed Acclimatization}

Before testing the transmission of ice-ice disease, seaweed was first acclimatized for 3 days. This acclimatization was carried out to adapt seaweed to new environmental conditions. During acclimatization, the media were given liquid organic fertilizer (POC NASA) as much as $5 \mathrm{ml}$ per aquarium volume of 80 liters. The test container was equipped with constant aeration.

\section{Observation of Clinical Symptoms}

The determination of the health status was based on clinical signs macroscopically, which is characterized by changes in the thallus to become rough, wilted and wrinkled followed by the appearance of white spots on the surface of the thallus seaweed. Thallus wet weight measurements were carried out every hour for 5 days.

\section{Carrageenan Content Analysis}

Determination of seaweed carrageenan concentration was expressed in the percentage of carrageenan dry weight of seaweed following the method of Hayashi et al.(2007). The analysis of carrageenan content was performed on the seaweed thallus in each treatment, including the negative control.

\section{Histological examination}

Histology observation is a microscopic observation to see changes in tissue structure due to the transmission of ice-ice disease from seaweed which is attacked by ice-ice disease to healthy seaweed at each treatment. Observation of the structure of the seaweed tissue was carried out for 5 consecutive days. Histological observation and the staining of Mayers Hematoxylin and Eosinfollowed the procedure by Jaiswal et al. (2019).

\section{Data analysis}

This study used a Completely Randomized Design model. The effect of the treatment was tested by using the Analysis of Variance, if there was an effect, then Duncan's further test analysis was carried out.

\section{RESULTS}

The spread of ice-ice disease in cultivated seaweed organisms is closely related to the process of transferring disease agents from thallus affected by ice-ice to healthy thallus. The symptoms of ice-ice disease are indicated by changes in the color of the thallus which leads to symptoms of the emergence of ice-ice disease.

Analysis of variance showed that there was no significant interaction between treatment and time with a value of 0.99 ( $p>0.05)$, while the severity of the treatment of infected thallus to the transmission of ice-ice disease showed a significant effect with a value of 
$0.03(p<0.05)$. Treatment with the transmission time level showed a significant influence on the appearance of ice-ice disease 0.01 ( $p$ $<0.05)$. The results of the statistical analysis did not show the effect of each treatment, but based on the observation time they showed a significant effect in each treatment. Based on Duncan's test results, it shows that the treatment on the fifth day has a lower value (28.0472) compared to the first (32.451), second (32.6769), third (32.2361), and fourth (30.2365) days. This shows that over time the transmission process of ice-ice pathogens increases in the thallus of healthy seaweed.

This can be further proven by the appearance of ice-ice disease symptoms from each treatment compared to negative controls that did not show ice-ice symptoms during the observation. The speed of transmission of ice-ice disease to healthy seaweed thallus shows different results. In treatment $A$, transmission of ice-ice disease infection occurred on the fourth day. Treatment $B$, the transmission occurred on the third day. Treatment $C$, the transmission occurred on the fourth day. While treatment $\mathrm{D}$, the transmission occurred on the second day.

Transmission of ice-ice caused morphological changes in seaweed thallus showing the same symptoms in each treatment. The change begins with a change in the condition of the thallus that has lost mucilage on the surface of the thallus. These conditions cause the surface of the thallus to become rough and gradually change color.
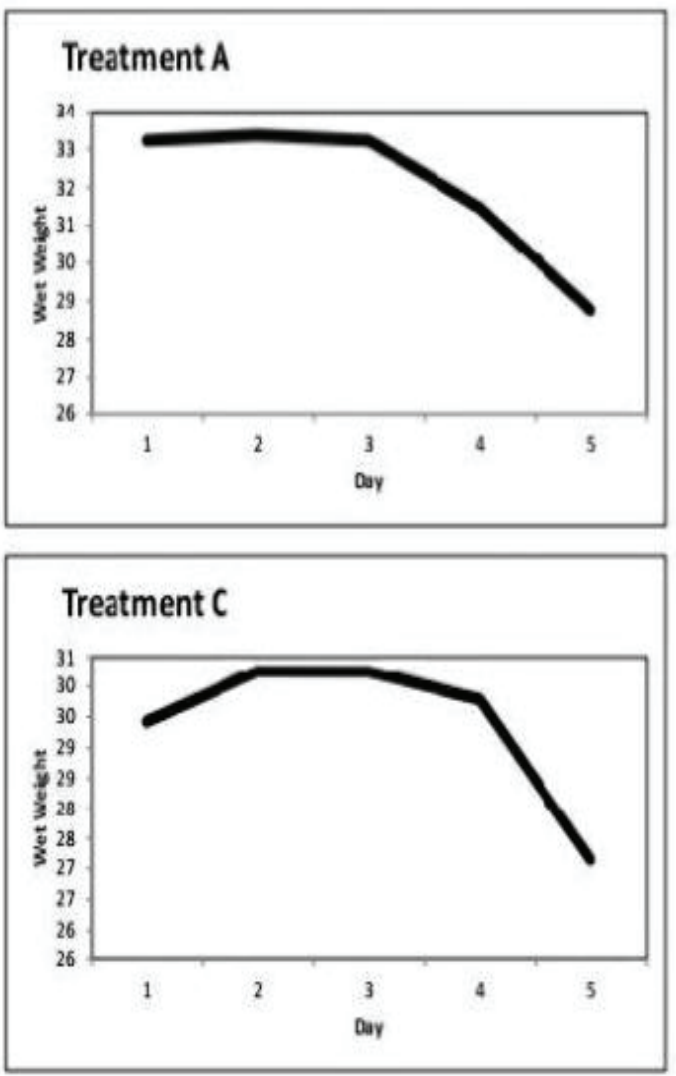

Changes in the thallus surface conditions and changes in color and the appearance of bleaching at the tip of the thallus were followed by changes in the wet weight of the thallus seaweed (gram). The relationship is shown by the tendency to decrease the fresh weight of seaweed thallus after transmission test (Fig.1). The change in color and the decrease in wet weight cause changes in the conditions of the thallus tissue. According to the results of the histological observations, the thallus tissue of the seaweed showed differences in the structure of the tissue (Fig. 2). The healthy condition of seaweed tissue shows that the components of the cells making up the tissue are intact such as cortical cells and modular cells are still compact, neatly arranged, while the seaweed tissue structure infected with ice-ice disease shows the tissue structure from the first day to the fifth day showing changes in cell degradation (cells making up damaged tissue or lysis).

Changes in carrageen an content of seaweed are different in a healthy thallus condition with seaweed with ice-ice disease and can be seen in Table 1. According to the analysis of the carrageenan content of the seaweed thallus in the negative control, the values ranged between $28 \%$ and $35 \%$. When compared with seaweed thallus content from the transmission test results, the range of carrageenan content values is lower with a range of $2.9 \%-4 \%$.
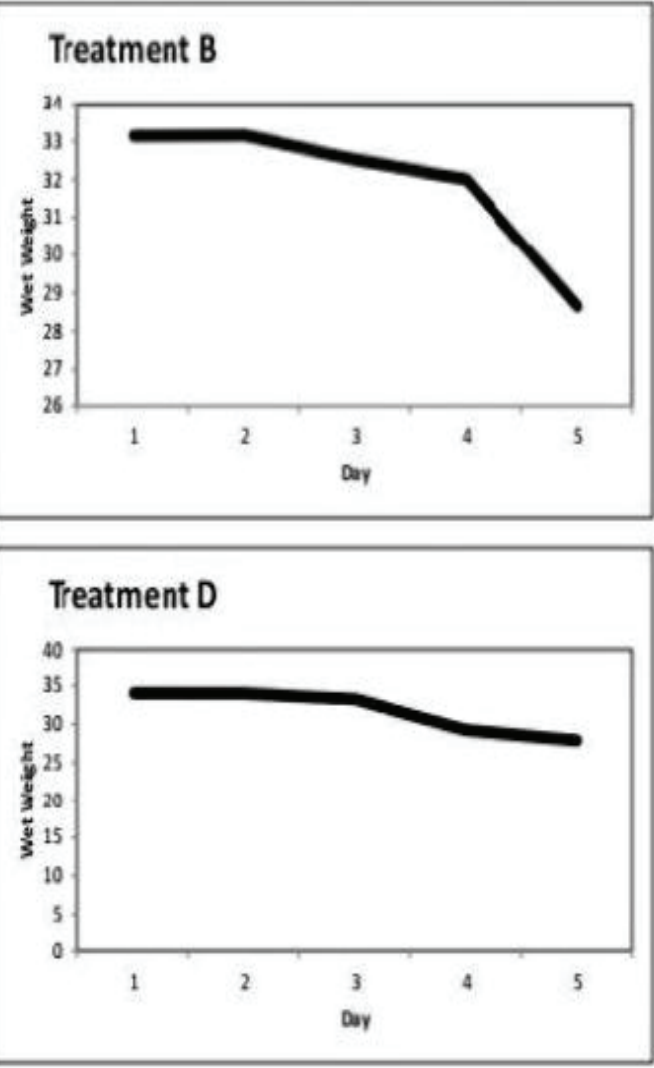

Figure 1. Changes in biomass during the experiment from day 1 to 5 . 
The transmission test shows that there is a change and causes a tendency to significantly decrease carrageenan levels with each treatment. Based on the analysis of carrageenan content of seaweed after transmission test, show a tendency to decrease carrageenan levels significantly from each treatment. Based on the results of the analysis of variance $(p<0.05)$, it shows an interaction of the level of severe treatment of infected thallus with the transmission test time to the response to decrease in carrageenan content. The interaction of each treatment level was determined by further statistical tests with the Duncan test. The results of the analysis show the differences of each interaction level of treatment before and after the ice-ice disease transmission test.

\section{DISCUSSION}

In fish, shrimp and seaweed cultivation activities, disease attacks are the main obstacles (Loch \& Faisal, 2015; Mohamad et al., 2019; Dey et al., 2019; Ward et al., 2019). The results of this study indicate that the transmission of ice-ice disease to healthy seaweed thallus causes discoloration and weight loss.

The phenomenon observed in the present study of ice-ice disease has similarities with those reported by Ask et al. (2003), Yong et al. (2015) and Tsiresy et al. (2016), that the incidence of ice-ice disease in

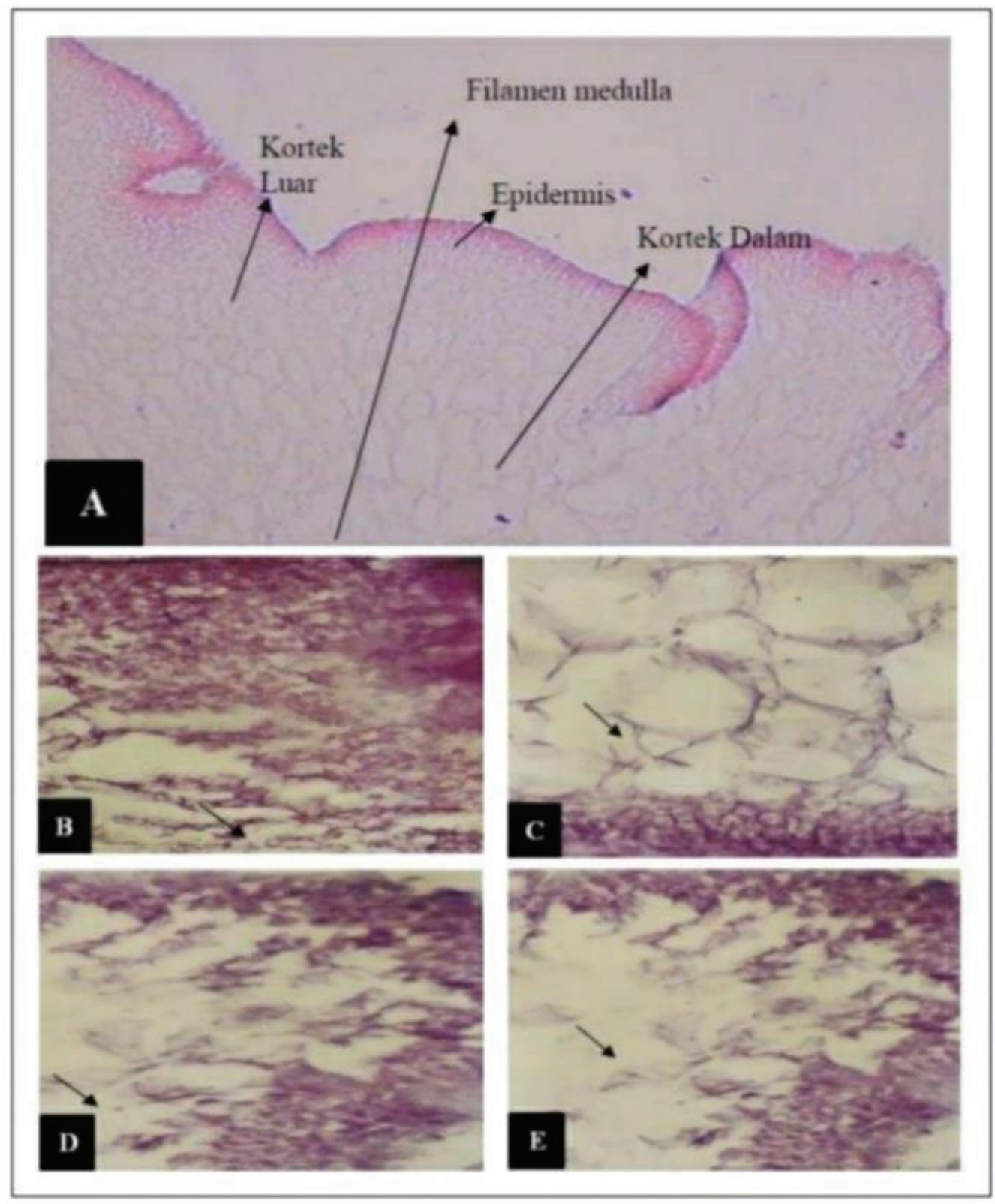

Figure 2. Photomicrograph of seaweed thallus tissue Kappaphycus alvarezii that is attacked by ice-ice disease $(A=$ Day $0, B=$ Day $2, C=D a y ~ 3, D=D a y ~ 4, E=$ Day 5) [Arrows in image B-E indicate the occurrence of cell death or lysis]. 
Table 1. Results of carrageenan content analysis on day of the experiment

\begin{tabular}{lc}
\hline Treatment & Carrageenan content (\%) \\
\hline A & $4,0 \%$ \\
B & $3,1 \%$ \\
C & $3,1 \%$ \\
D & $2,9 \%$ \\
Negative control & $28-35 \%$ \\
\hline
\end{tabular}

a seaweed cultivation region begins with changes in thallus that are experiencing stress, followed by bleaching and ultimately thallus damage. Stress characterized by changes in the color of the thallus is an early symptom of seaweed that has a disruption of ice-ice disease, along with the maintenance of the thallus tip turns white and finally porous (Sulu et al., 2003).

In addition, the transmission of ice-ice shows different tissue structures in seaweed that show changes in the degradation of cells making up the lysed tissue. Transmission of disease agents can cause changes in tissue structure (Magi et al., 2009; Senapin et al., 2018). This is due to the attachment of disease agents from the organism to the production of extracellular substances, that is highly correlated with time and weight loss of the new hosts due to the lysis of new host cells (Salyers \& Whitt, 1994).

Ice-ice infection also causes a decrease in carrageenan content in K. alvarezii seaweed (Rantetondok \& Latama, 2017; Ward et al., 2019). This is indicated by the loss of pigment due to lysis of the cells making up seaweed tissue. Another impact of cell lysis is the occurrence of significant degradation of organic substances from the thallus tissue of seaweed. The study of Mendoza et al. (2002), showed that the viscosity and carrageenan levels of $K$. alvarezii seaweed thallus decreased when ice-ice infection occurred.

This condition is in line with the results of research Hayashi et al. (2010) that, the condition of seaweed thallus which experienced pigment loss and showed symptoms of ice-ice disease had a low carrageenan content ranging from $0.5 \%-25 \%$. The quality of $K$. alvarezii seaweed is determined by carrageenan content which ranges from $32 \%-75 \%$, and decreases its quality when it is below that range (Munoz \& Sahoo, 2004). The content of carrageenan and gel strength decreased significantly when the symptoms of ice-ice disease began to appear in the thallus, and decreased with time and the level of thallus damage. The decrease in carrageenan content is directly proportional to the time of bacterial infection (Riyaz et al., 2020).

\section{CONCLUSION}

The results of this study indicate that the transmission of ice-ice disease can occur horizontally from thallus affected by ice-ice to healthy thallus. This transmission causes discoloration accompanied by a decrease in thallus weight. Transmission also causes changes in tissue structure and decreases carrageenan content.

\section{REFERENCES}

Aeni, 0. N., L. 0. M. Aslan, W. Iba, A. B. Patadjal, M. Rahim \& M. Balubi. Effect of different seedling sources on growth and carrageenan yield of seaweed Kappaphycus alvarezii cultivated in Marobo Waters, Muna Regency, Southeast (Se) Sulawesi,Indonesia. IOP Conf. Series: Earth and Environmental Science 382: 1-9. D0I:10.1088/1755$1315 / 382 / 1 / 012015$

Ask, E. I. \& R. V. Azanza. 2002. Advances in cultivation technology of commercial eucheumatoid species: a review with suggestions for the future research. Aquaculture 206: 257-277. D0I:10.1016/S00448486(01)00724-4

Barbosa, M., L. Cavalcante, C. Souza \& P. Gomez. 2013. Kappaphycus alvarezii (Gigartinales, Rhodophyta) cultivated in Brazil: is it onlyone species. Journal of Applied Phycology 25: 1143-1149. D0l: 10.1007/s10811-012-9952-8

Ben-Asher, R., S. Ravid, M. Ucko, M.Smirnov \& 0. Lahav. 2019.Chlorine-based disinfection for controlling horizontal transmission of VNNin a seawater recirculating aquaculture system growing European seabass. Aquaculture 510: 329-336. D0I:10.1016/j.aquaculture.2019.06.001

Bindu, M. S. \& I. A. Levine. 2011. The commercial red seaweed Kappaphycus alvarezii an overview on farming and environment. Journal of Applied Phycology 23: 789-796. D0I:10.1007/s10811-010-9570-2

BIXLER, H. J. \& H. PoRSE. 2010. A decade of change in the seaweed hydrocolloidsindustry. Journal of Applied Phycology 23: 321-335. DOI:10.1007/s10811-010-9529-3

Dey, B. K., G. H. Dugassa,S . M. Hinzano \& P. Bossier. 2019.Causative agent, diagnosis and management of white spotdisease in shrimp: A review. Reviews in Aquaculture 12(2): 1-44. D0l:10.1111/raq.12352

Hayashi, L., E. J. de Paula \& F. Chow. 2007.Growth rate and carrageenan analyses in four strains of Kappaphycus alvarezii (Rhodophyta, Gigartinales) farmed in the subtropical waters of São Paulo State, Brazil. Journal of Applied Phycology 19: 393-399. D0I:10.1007/ s10811-006-9135-6

Hayashi, L., N. S. Yokoya, S.Ostini, R. T. L. Pereira, E. S. Braga \& E. C. Oliveira. 2010. Nutrients removed by Kappaphycus alvarezii (Rhodophyta, Solieriaceae) in integrated cultivation with fishes in re-circulatingwater. Aquaculture 277: 185-191. D0l:10.1016/j.aquaculture.2008.02.024

Hung, L. D., K. Hori, H. Q. Nang, T. Kha \& L. T. HoA. 2009. Seasonal changes in growth rate, carrageenan yieldand lectin content in the red alga Kappaphycus alvarezii cultivated in Camranh Bay, Vietnam. Journal of Applied Phycology 21: 265-272. D0I:10.1007/s10811008-9360-2

Hurtado, A. Q., I. C. Neish \& A. T. Critchley. 2015. Developments in production technology of Kappaphycus in the Philippines: more than four decadesof farming. Journal of Applied Phycology 27: 1945-1961. DOI:10.1007/s10811-014-0510-4

JaISWAL, L., S. Shankar \& J. RHIm. 2019.Carrageenan-based functional hydrogel film reinforced with sulfurnanoparticles and grapefruit seed extract for wound healing application. Carbohydrate Polymers 224: 115-191. D0I:10.1016/j.carbpol.2019.115191 
KarthiKeyan, K. \& R. Sudhakaran. 2018.Experimental horizontal transmission of Enterocytozoon hepatopenaei in post-larvae of white leg shrimp, Litopenaeus vannamei. Journal of Fish Diseases 42(3): 397-404. DOl:10.1111/jfd.12945

Kasim, M. \& A. Mustafa. 2017. Comparison growth of Kappaphycus alvarezii (Rhodophyta, Solieriaceae) cultivation in floating cage and longline in Indonesia. Aquaculture Reports 6: 49-55. D0I:10.1016/j. aqrep.2017.03.004

Korun, J. \& G. Timur. 2008. Marine vibrios Associated with diseased sea bass (Dicentrarchus labrax) In Turkey. Journal of Fisheries Sciences 2(1): 66-76. DOI:10.3153/jfscom.2008007

Largo, D. B., F. FukAmI,T. NishiJIMA \& M. OLINo. 1995. Laboratory induced development of the ice-ice disease of the farmed red algae Kappaphycus alvarezii and Eucheuma denticulatum (Solieriaceae, Gigartinales, Rhodophyta). Journal of Applied Phycology 7: 539-543. DOI:10.1007/BF00003940

LoCH, T. P. \& M. FaISAL. 2015. Emerging flavobacterial infections in fish: A review. Journal of Advanced Research 41(5): 829-845. D0I:10.1016/j.jare.2014.10.009

Loureiro, R. R., R. P. ReIS \& A. T. CRitchley. 2010. In vitro cultivation of three Kappaphycus alvarezii (Rhodophyta, Areschougiaceae) variants (green, redand brown) exposed to a commercial extract of the brownalga Ascophyllum nodosum (Fucaceae, Ochrophyta). Journal of Applied Phycology 22: 101-104. D0l:10.1007/s10811009-9412-2

Luhan, M. R. J., S. Sheryll-Avañcena \& P. M.Jonalyn. 2015.Effect of shortterm immersion of Kappaphycus alvarezii (Doty)Doty in high nitrogen on the growth, nitrogen assimilation,carrageenan quality, and occurrence of "ice-ice" disease. Journal of Applied Phycology 27: 917-922. DOI:10.1007/s10811-014-0365-8

Magi, G. E., S. Lopez-Romalde, B. Magariños, J. Lamas, A. E. Toranzo \& J. L. ROMALDE. 2009. Experimental Pseudomonas anguilliseptica infection in turbot Psettamaxima (L.): a histopathological and immunohistochemical study. European Journalof Histochemistry 53: 73-80. DOI:10.4081/ejh.2009.e9

Manin, B. 0. \& J. Ransangan. 2011.Experimental evidence of horizontal transmission of Betanodavirus inhatchery-produced Asian seabass, Lates calcarifer and brown-marbled grouper, Epinephelus fuscoguttat us fingerling. Aquaculture 321: 157-165. D0l:10.1016/j.aquaculture.2011.08.021

Mendoza, W. G., N. E. Montano, E. T. Ganzon-Fortes \& E. R. D. Villanu. 2002. Chemicaland Gelling Profile of ice-ice Infected Carageenan from Kappaphycus striatum (Schmitz) Doty "Sacol" Strain Solieciriciae, Gigartinales, Rhodophyta). Journal of Applied Phycology 14: 409-418. DOI:10.1023/A:1022178119120

Mohamad, N., M. N. Z. Amal, I. S. M. Yasin, M. Z. SaAd,N. S. NasRuddin, N. Al-saari, S. Mino \& T. Sawabe. 2019. Vibriosis in cultured marine fishes: a review. Aquaculture 512: 01-17. D0I:10.1016/j.aquaculture.2019.734289

Munoz, J., Y. Freile-Pelegrín \& D. Robledo. 2004. Mariculture of Kappaphycus alvarezii (Rhodophyta, Solieriaceae) color strains intropical wa- ters of Yucatán, México. Aquaculture 239: 161-177. D0I: 10.1016/j. aquaculture.2004.05.043

Munoz, J. \& D. SAH0о. 2004. Impact of Large Scale Kappaphycus alvarezii Cultivation in Coastal Water of India. XIX th International seaweed Symposium, Kobe,Japan, Program and abstracts. $121 \mathrm{p}$.

Nadirah, M., H. H. RuHil, K. C. A. Jalal \& M. Najiah. 2012. Occurrence of Plesiomonas shigelloides in cultured red hybrid tilapia (Oreochromis niloticus) from tropical rivers, east coast Malaysia. Pakistan Journal Biological Sciences 15: 600-603. D0I:10.3923/pjbs.2012.600.603

OH, W. T., J. H. KIm, J. W. Jun, S. S. Giri, S. Yun, H. J. KIm, S. G. KIm, S. W. Kım, S. J. HAN, J. KWON \& S. C. PARK. 2019. Genetic Characterization and Pathological Analysis ofa Novel Bacterial Pathogen, Pseudomonas tructae, in Rainbow Trout (Oncorhynchus mykiss). Microorganisms 7(432): 01-12. D0I:10.3390/microorganisms7100432

Porse, H. \& B. Rudolph. 2017. The seaweed hydrocolloid industry: 2016 updates, requirements, and outlook. Journal of Applied Phycology 29: 2187-2200. DOI:10.1007/s10811-017-1144-0

Rantetondok, A. \& G. Latama. 2017. Epiphytic and ice-ice diseases of seaweed, Kappaphycus alvarezii and its effect on growth rate and carrageenan quality. International Journal of Aquaculture 7(21): 134-138. D0I:10.5376/ija.2017.07.0021

Riyaz, S. U. M., S. Nalini, G. Kavitha, S. A. D. Sutha \& D. Inbakandan. 2019. Characterization and identification of isolated bacteria from ice-ice disease infected seaweed Kappaphycus alvarezii. Indian Journal of Geo Marine Sciences 48(08): 1286-1290.

Riyaz, S. U. M., N. S. Prabhu, S. Nalini, G. Tejaswini, H. J. Christy \& D. InbakanDAN. 2020. Microbiome identification from ice-ice disease infected Kappaphycus alvarezii using 16S rRNA gene sequence analysis and in silico docking studies against carrageenan degrading bacteria. Biocatalysis and Agricultural Biotechnology 27: 101870. DOl:10.1016/j.bcab.2020.101707

Salyers, A. A. \& D. D. Whitr. 1994. Bacterial Pathogenesis: A Molecular Approach. ASM Press, Washington D.C.420 p.

Senapin, S., H. T. Dong, W. Meemetta, W. Gangnonngiw, P. Sangsuriya, R. VaniCHVIRIYAKIT, M. SonthI \& B.NuAngSAEng. 2018. Mortality from scale drop disease in farmed Lates calcarifer in Southeast Asia. Journal of Fish Diseases 42(1): 119-127. DOI:10.1111/jfd.12915

Solis,M. J. L., S. Draeger, E. E. Thomas \& T. E. E. de la Cruz. 2010. Marine derived fungi from Kappaphycus alvarezii and $K$. striatum as potentialcausative agents of ice-ice disease in farmed seaweeds. Botanica Marina 53: 587-594. D0l:10.1515/bot.2010.071

Sulu, R., L. Kumar, C. Hay \& T. PICKering. 2003. Kappaphycus alvarezii in the pacific: review of introductions and field testing proposed quarantinem protocols. The Institute of Marine Resources (IMR), The University of the South Pacific. Also available at: http://marineagronomy.org/sites/default/files/Sulu.\%202006.Kappaphycus $\% 20$ introductions $\% 20 \% 26 \% 20$ quarantine.pdf

Syafitri, E., S. B. Prayitno, W. F. Ma'ruf \& 0. K. Radjasa. 2017. Genetic diversity of the causative agent of ice-ice disease of the seaweed Kappaphycus alvarezii from Karimunjawa island, Indonesia. IOP Conf. Series: Earth and Environmental Science 55: 1-8. DOI:10.1088/1755-1315/55/1/012044 
Tsiresy, G., J. Preux, T. Lavitra, P. Dubois, G. Lepoint \& I. Eeckhaut. 2016.Phenology of farmed seaweed Kappaphycus alvarezii infestation by the parasitic epiphyte Polysiphonia sp. in Madagascar. Journal of Applied Phycology 28: 2903-2914. DOI:10.1007/s10811-016-0813-8

VaIRAPPAN, C. S. 2006. Seasonal occurrences of epiphytic algae on thecommercially cultivated red alga Kappaphycus alvarezii (Solieriaceae,Gigartinales, Rhodophyta). Journal of Applied Phycology 18: 611-617. DOI:10.1007/978-1-4020-5670-3_46

Ward, G. M., J. P. Faisan-JR, E. J. Cottier-Cook, C. Gachon, A. Q. Hurtado, P. E. Lim, I. Matoju, F. E. Msuya, D. Bass \& J. Brodie. 2019.A review of reported seaweed diseases and pestsin aquaculture in Asia. The Journal of the World Aquaculture Society 1: 1-14. D0I:10.1111/jwas.12649
Yong, Y. S., W. T. L. Yong, V. Y. Thien, S. E. NG, A. Anton \& S. Yassir. 2015. Acclimatization of micropropagated Kappaphycus alvarezii (Doty) Doty ex Silva (Rhodophyta, Solieriaceae) in outdoor nursery system. Journal of Applied Phycology 27: 413-419. D0I:10.1007/s10811014-0289-3

Yunque, D. A. T., K. R. Tibubos, A. Q. Hurtado \& A. T. Critchley. 2011. Optimization of culture conditions for tissueculture production of young plantlets of carrageenophyte Kappaphycus. Journal of Applied Phycology 23: 433-438. DOI:10.1007/s10811-010-9594-7

Zuniga-Jara, S. \& M. Marin-Riffo. 2015. Bioeconomic analysis of smaII-scale cultures of Kappaphycus alvarezii (Doty) Doty in India. Journal of Applied Phycology 28: 133-1143. DOI:10.1007/s10811015-0616-3 